Article

\title{
Construction History and the History of Construction Cultures: Between Architecture and Engineering in Portugal
}

\author{
João Mascarenhas-Mateus $\mathbb{D}$ \\ CIAUD—Research Centre for Architecture, Urbanism and Design, Lisbon School of Architecture, University of \\ Lisbon, 1349-063 Lisboa, Portugal; joao.m.mateus@fa.ulisboa.pt
}

Received: 14 February 2020; Accepted: 26 March 2020; Published: 28 March 2020

\begin{abstract}
This paper aims to debate the epistemological boundaries of construction history, in relation to the fields of history of architecture and the history of engineering, using Portugal as a case study. The concept of construction culture is used to broaden the analysis, avoiding the old dichotomy between architects and engineers. Instead, construction history (understood as the history of construction cultures) aims to integrate the contributions of all actors in this sector of activity, such as contractors, materials and machine producers, traders, and public and private institutions. The history of architecture and the history of engineering in Portugal serves to illustrate the extent to which the study of how a community built in a particular space, at a particular time, is fragmented in the present age. The conclusions highlight the limits of a history that has been interpreted mainly from the point of view of the activity of architects and engineers. This paper also explores the potential of a history of construction cultures as a constructum in constant transition and under constant discussion, capable of explaining the set of problems involved in this millennia-old human activity.
\end{abstract}

Keywords: construction history; construction culture; epistemology; architecture history; engineering history; Portugal

\section{Introduction}

Construction history is a field of knowledge that has been a particular focus of interest over the last three decades. This has given rise to six international conferences, as well as the founding of six research societies in the United Kingdom, Spain, the US, France, Germany and Portugal; the creation of specialist journals in the United Kingdom and France; the funding for research projects; and the publication of numerous monographic works and other types of literature on the subject [1].

Since the founding in 1983 of the first research society in the sphere-the Construction History Society in the United Kingdom-various authors have worked on the epistemological aspects of this field of knowledge, proposing the definitions and limits of its study. This society's journal, Construction History, itself proposes the following definition of the discipline: "Construction History is the study of the development of the building industry." Santiago Huerta defines the discipline as follows: "Construction history is the chronological study of the techniques applied in architectural and civil engineering works" [2] (p. 31). Bill Addis defines it as the study of "the historical development of engineering design procedures" [3] (p. 69). The latter two definitions are based on two well-established disciplines: engineering and architecture.

This paper aims to contribute to the debate surrounding the definition of the sphere of study of construction history, proposing a vision based on the concept of the history of construction cultures to bring together the aforementioned definitions, broaden the purposes of relevant analyses, and relativize 
its epistemological limits within a vision of history that aims to be free from any rationalist exaltation of the progress of modernity.

The case of Portugal and certain aspects of the limits on the fields of action of the history of architecture and the history of engineering in this country serve to illustrate the way in which the study of Portuguese construction cultures has been fragmented. These factors offer routes for establishing spheres of study encompassed by construction history in general, based on the principle that the issues to be studied are similar, whether the context is in Portugal or in any other country with its own idiosyncratic features.

\section{Epistemological Issues}

Studying buildings, which can be themselves understood as a material production of cultures in space and time, requires tackling the complex issue of how we analyze the ontology of any given culture based on the principle that construction is an essential human activity.

Taking an initial Aristotelian approach to the great, primordial question of what it means to study a given culture from the point of view of how a community is built in a particular space, at a particular time, we might say that to get to know construction cultures of the past, we need to answer the questions of who (built) what, when, where, why, in what way, and by what means?

If we delve into the past, we can see that some of the hierarchical knowledge on the abovementioned circumstantial questions, which may be useful in establishing the circum-stare of construction history, were addressed by different disciplines that consolidated their positions during the nineteenth century. In this sphere, architecture history had a central role in answering the questions of the what, who, where and when - and to a certain extent the why and in what way-people built.

Alongside this, other disciplines have also contributed to knowledge on the way in which people have built, based above all on synthetic, a priori judgements. According to the history of techniques, in particular, according to the foundational works by Oswalt [4] and Petroski [5], technological progress in construction has made use of different improvements to tools (mobile artefacts) and working procedures designed to create constructions (immobile artefacts). Meanwhile, engineering history has focused on innovation in the methods required to achieve technical aims [6]. Guided by a progressive narrative of the inventions and innovations of techniques implemented by military and civil engineers within the engineering specialities carved out by an industrial society, the history of engineering has approached the question of construction as an auxiliary activity to the continuing development of the ideal global industrialized society [7].

Nevertheless, as of the second half of the twentieth century, a paradigm shift in the way we study the past, determined by the Annales School, served to blur the most well-defined lines of action within history as a discipline [8]. This shift also highlighted that, when establishing the main features of a topic or question for study, it is not enough to differentiate one field of knowledge from another. As a result, we now find that a systematic and rational analysis that seeks to find an ideal, complete body of knowledge of facts and data, or a single scientific truth, is, in its own premise, a flawed method [9].

Thus, history-which for a long time had focused on classifying great moments in innovation and the emergence of the academic schools that gave rise to these moments-began to include popular culture as an object of study, in which the knowledge accumulated over generations is contrasted with the methods of empirical science. The classification of these vernacular cultures as a category of knowledge [10] is a departure from the radical, disparaging pre-conceptions applied to such cultures to accept their merits as distinct from the structured knowledge used by the elites and to recognize their full and joint contributions to "scientific discoveries". Despite these changes, the history of construction science, and outstanding authors like Edoardo Benvenuto, Joël Sakarovitch, and Karl-Eugen Kurrer, have continued to focus, above all, on the evolution of the links between the various sciences to improve the calculations and a priori modelling of the behaviour of the materials and structures employed in built structures [11-13]. 
Meanwhile, the need to understand construction history through an analysis of the transformation of a community's knowledge capital expressed in the activity of construction has led many researchers in well-established disciplines to displace existing epistemological frontiers. This was the case for building and construction archaeology, which advocated the importance of the information that could be gleaned from observing buildings themselves [14,15]. Similarly, economic and social history has contributed vital context that is linked, for example, to the organization of companies, the relations between industry and construction, and the impact of national infrastructures on territories [16].

\section{History and Distinction: Architects and Engineers in Portugal}

The definition and hierarchy of the various tasks involved in construction processes, as we classify them today, are the recent result of the transformations made by scientism applied to the art of construction, its industrialization, and the establishment of successive institutions dedicated to providing a professional framework for the trades forming part of the construction sector. Searches in encyclopedias for the first known architect will often yield the name of the polymath Imhotep, who lived in the 27th century BC and was responsible for building the stepped pyramid of Djoser at Saqqara, Egypt. Paradoxically, he is named as the first builder, the first architect, the first engineer, and even the first medical doctor recorded in history.

Until the term "architect" (which has its roots in Ancient Greek and was popularized in the 16th century), the people responsible for designing and creating constructions went by various names: master builder, master stonemason, master carpenter, and so on. In contrast, historical sources are less clear when it comes to naming the owner of a work, considering this to be the entity for whom the work is to be executed, who should have full control over the project program, from design to execution. The person that commissioned the work was often apparently responsible for the project's development and execution, coordinating all of the knowledge required by the complex activity of construction. As of the eighteenth century, the creation firstly of engineer corps and fine art academies and subsequently the system of polytechnic teaching; the delimitation of academic curricula; the founding of professional associations in the range of construction trades; and successive legal frameworks defining the skills involved in the field, constituted some of the mechanisms and instruments responsible for the aforementioned changes. This division of powers has given rise to a wide variety of academic and professional frameworks whose make-up still depends today on the country and culture to which they belong. The duality of engineer/architect still seems to absorb all the attention of architecture and engineering faculties, clearly overlooking the historical importance of collectives such as construction companies and individuals, including master craftsmen or non-specialized workers.

Today, despite increasing specialization among professionals in the construction sector, the contemporary architect often claims for himself the role of demiurge in the building process as a whole (including not only the design but also the execution), despite the fact that he/she frequently possess insufficient training in the domains of structural calculations, material science, and building techniques. In fact, the modern responsibilities of an architect are the result of a cultural, political, economic, and social "construction" that must be taken into account if we are to understand the discipline of architecture history today.

Since the works by authors such as Giorgio Vasari (1511-1574), Leon Battista Alberti (1404-1472), and Francesco Milizia (1725-1798), architecture history has focused much of its efforts on providing a critical analysis of detailed surveys of historical buildings, on discussing the context of architectural creation, and on establishing "who was (or had been)" worthy of belonging to an immortal pantheon of great architects. Such issues did much to shape the discipline. Today, many researchers consider architecture history to mean not only the history of architectural theory-particularly the architectural theory of modernity-but also a critical approach to the relationships between the frameworks of knowledge of the most highly regarded architects and their creations. In large part due to the basic training that these researchers (architects or art historians) have, architecture history tends to be written 
in a way that projects the problems of the present onto the past [17]. Nevertheless, some great early theorists such as Gottfried Semper (1803-1879), Eugène Viollet-le-Duc (1814-1879), August Choisy (1841-1909), and Giovanni Battista Milani (1876-1940) produced studies on the creation and evolution of architectural styles that found close links not only between the aspect (symbolic value) and form (constructive value) of constructions but also between the technical pragmatism of construction and architectural design in Europe and in its hybridizations with Asia, Africa, or America. This recourse in the historical analysis of material cultures of architecture has persisted, appearing in more recent studies such as those of Kenneth Frampton, who explores how "the built" came into existence over the course of the nineteenth and twentieth centuries out of the combination of three main vectors: topos, typos, and tectonics, the last of which can be understood to refer to the builder and the construction process [18].

Perhaps because to define a style is to also define an identity, and despite the openness of the aforementioned authors to the cultural question of how people built over the course of history, architecture history has continued to pay more attention to questions of conception than execution, seeking to legitimize the activity of architects and distinguish it from other professions, such as engineering.

With the aim of illustrating these limitations of epistemology and method, we will now offer a brief summary of how a distinction was made between architects and engineers in Portugal, how the country built its own histories, and what its relationship is with construction history.

Since 1836, the teaching of architecture in Portugal has been framed within other arts such as painting and sculpture at the fine arts academies of Lisbon and Porto, respectively, which were classified as schools of fine arts in 1881 and 1898, respectively. Despite the reforms of 1950-1951, which transformed the schools into higher education institutions, architecture faculties were not created in Lisbon and Porto until the year 1979 and in Minho until 1996. Those faculties were followed by new architecture departments in universities, such as Coimbra (1988) and Évora (2001), as well as masters in architecture programs, such as the ones taught at the Instituto Superior Técnico de Lisboa (Higher Technical Institute of Lisbon, 1998) and at the University of Beira Interior [19]. In the corporate sphere, the Real Associação dos Arquitectos Civis e Arqueólogos Portugueses (Royal Association of Portuguese Civil Architects and Archaeologists) was founded in 1862, while the Sociedade dos Arquitectos Portugueses (Society of Portuguese Architects), founded in 1902, was replaced in 1932 by the Sindicato Nacional de Arquitectos (National Architects' Union), followed in 1978 by the Associação dos Arquitectos Portugueses (Association of Portuguese Architects) and later in 1986 by the Ordem dos Arquitectos (Institute of Portuguese Architects).

For engineers, there was the Real Corpo de Engenheiros (Corps of Royal Engineers), created in 1787, which gave rise to the Ministry of Public Works in 1852. It was the civil engineer corps of this new institution that began to produce an auxiliary body of architects that was responsible for the creation of the first modern infrastructures, as well as for founding the first industries in the country, consolidating an undisputed central role in the profession at the highest levels of state administration and the business world. At that time, following the French model, advanced engineers did their preparatory studies at the polytechnic schools of Lisbon and Porto, gaining their diploma at the military academy. As of 1864, industrial education systems were in charge of training auxiliary engineers. In the year following the republican revolution of 1910, the Instituto Superior Técnico (Higher Technical Institute) was created following the German model, while the Engineering Faculty of Porto opened in 1915 [20]. These are the two main schools that currently exist in Portugal. In the corporate sphere, the Associação de Engenheiros Civis Portugueses (Association of Portuguese Civil Engineers), founded in 1869, became the Ordem dos Engenheiros (Portuguese Institute of Engineers) in 1936. The capacity of civil engineers to steer the direction of public works continued under the Second Republic, or Estado Novo, the autocratic regime that took power in Portugal following the 1926 revolution, installing António de Oliveira Salazar (1889-1970) as Prime Minister between 1932 and 1968, which was overturned during the revolution of 25 April 1974. This situation persevered during a period in which new infrastructures were built with the financial support of Portugal's membership of 
the European Community as of 1986. Nevertheless, as of 2009, with the transposition of European standards into Portuguese legislation, the responsibility for architecture projects, which had until then been afforded to engineers since 1973, became the sole preserve of architects. Meanwhile, the recent crisis in the construction industry only served to reinforce the role of architects in the spheres of urban and territorial management.

This brief account of the context and dynamics of transformation inherent in historic processes can help us better understand the current state of teaching and research in Portugal in the disciplines of architecture history and engineering history. In fact, if we consult the available curricula for undergraduate and postgraduate courses in architecture, we will find typical courses on the "universal" and national history of architecture, in particular the study of the plain style (or "estilo chão", as defined by the US author George Kubler (1912-1996)), the "manuelino" and "pombalino" styles, or the traditionalist style characteristic of the Estado Novo period. This model is followed by courses on art history in Portuguese universities. There are also research teams dedicated to each of the broad universal periods of history and each of the main topics in architecture history, while other teams are dedicated to particular aspects of Portuguese history, such as the architecture of the maritime expansion, colonial architecture, the import and adaptation of foreign models, and the architecture of Portuguese modernism. This organized research contributes, above all, to legitimizing the stylistic concepts of Portuguese architects and resolving post-Marxist and postcolonial problems [21,22].

Nevertheless, despite these dominant strands of study, it is possible to find some research that can make an indirect contribution to construction history in fields such as industrial architecture and the traditional vernacular techniques that can be used in heritage conservation and new, durable architectures [23,24]. Currently, the only course on construction history available in Portugal is an optional unit lasting one semester offered by the doctoral program of Lisbon's School of Architecture, University of Lisbon. It is, therefore, relevant to consider the question of why architecture history did not take on the role of synthesizing the lines of research concerned with how people built in the past. A partial response can be found in the contemporary concept of the role of the architect and the image that architects have (or wish to project) of themselves, as demonstrated above.

Turning now to the situation of the history of civil engineering, we can observe that there are no university courses offering instruction on the history of engineering, perhaps because some engineers consider the discipline's history to be too short to tell, or because other engineers believe that their corporate identity only came into being with the creation of the aforementioned Ministry of Public Works in 1852. In 2010, Professor Emanuel Maranha das Neves of the Instituto Superior Técnico de Lisboa, who was then a member of the Euro-CASE (European Council of Academies of Applied Sciences, Technologies and Engineering), concluded that engineers are a very important professional group with an identity forged over the course of 150 years, which has made a major contribution to the living standards of the Portuguese people [25]. In fact, the few existing pieces of research on the activity of engineers were written by academics in the field of economic and social history [26] or by engineers self-taught in history [27].

Based on this brief analysis of the Portuguese situation, we can see that the two fields of knowledge that prepare the training for the two most important categories of professionals working in the Portuguese construction sector have very different attitudes toward history. One of these categories teaches and writes a great deal on their own history. The other does not teach its history and only writes sporadically on the topic. In their own way, both attitudes contribute more to a corporate affirmation and to making a distinction between professionals than to seeking a history that might help them obtain common knowledge on the history of how people built in the past.

\section{Construction History, Contemporaneity, and Cross-Cutting Lectures}

As can be observed in the case of Portugal, architecture professionals project an image of their own activity that seems to relativize or even ignore the contributions made by other professions to the history of how we built in the past. This same observation led authors such as Neil Leach to propose 
opening up the history of architecture to cultural studies and to environmental challenges, affirming that: "The door is the door to the other. Architecture has likewise remained convinced of its own exclusion from other discourses. Architecture has not dared to cross the threshold of the door even though that door has remained open" [28] (p. ixi).

Mindful of this need, other researchers, such as Ian Borden and Jane Rendell (2000), identified different problems to be resolved in the discipline, including theory as an object of study, the framing of questions of cultural interpretation and translation, the critical nature of history and the historicity of terms, interdisciplinary integration, the self-critical development of the discipline, and the confrontation of theory and practice. Always seeking to defer to the activity of architects, they defended the following position:

We need, therefore, theorized histories of all kinds, those that deal with issues of gender and race, those that deal with mind and body, those that deal with materiality and idealism, those that bewitch and those that puzzle. We need theorized histories that will inform the ever-changing range of practices that intersect with cities and their spaces, with architecture. We need theorized histories that help us to think and act critically, now and in future. [29] (p. 14)

Meanwhile, the many studies presented at national and international conferences on construction history, such as those at the international conference held in Madrid in 2003 [30], which address the spectrum of other disciplines (the history of construction science, art history, the history of techniques, the history of engineering, social and economic history, museology, ethnography, anthropology, and so on), confirm a set of clear historiographical injunctions [31]:

- The interest of various disciplines (including architecture history and engineering history) in studying construction history;

- The common aim of studying how people built in certain historical spaces at particular times;

- The cross-disciplinary nature of construction history;

- The need to acknowledge a self-sufficient, consensual field of knowledge, crossing various defined epistemological frontiers;

- The importance of this new domain of knowledge, regardless of its practical usefulness to the everyday activity of researchers and professionals.

Thus, the identity crisis suffered by architecture history and engineering history, as well as the aforementioned injunctions, have led to calls for a discussion on the nature and future of construction history as a discipline, particularly in relation to the history of cultures or cultural histories, ceasing to exclusively serve certain fields of activity, such as architecture or engineering. When considering the circum-stare of construction history, we must be aware of the latently transitional nature of the epistemological limits of all disciplines:

Our advancement, unfortunately, will continue to require transitional designations. In the far future, all history will be history, all art will be art. But now we still need words to mark off worthy domains of experience and accomplishment that differ from those celebrated in the academy. [32] (p. 20)

In this context, an examination of the cultural shift in historiography proposed by authors such as Raymond Williams (1921-1988), Michel Foucault (1926-1984), Michel de Certeau (1925-1986), Clifford Geertz (1926-2006), and Pierre Bourdieu (1930-2002) does not entail making history of culture but rather analyzing the historical past of the economic, social, political, and cultural components of a culture. To mention a few of these historiographic inflexions, the seminal works of the neo-Marxist Raymond Williams on cultural materialism, particularly on the relationships between technology and culture, paved the way for new polysemic and polyconceptual channels. Foucault's technè is understood as work that one performs on oneself, as an invention that is inscribed in time and in history and is accumulated in space. Michel de Certeau examined the way that an individual is 
formed and that individual's relationship with industrial strategies. Geertz understood culture as systems of knowledge that are transmitted down the generations through specific symbols and codes. Bourdieu noted the importance of the habitus in this transmission of cultural capital or knowledge.

Aware of the impossibility of objectively reconstructing the past, and with a view to avoid falling foul of the most radical historical relativism, we can develop a good definition of construction culture according to the words of Jane Morley: "building culture denotes the individuals, groups, organizations, and industries whose work, practices, and products relate to the construction of the man-made environment" [33] (p. 19). This concept is refined to perfection by Howard Davis: "the culture of building is the coordinated system of knowledge, rules, procedures, and habits that surrounds the building process in a given place and time" [34] (p. 5).

Knowledge of the historical past of these systems of knowledge on the activity of building, therefore, involves the analysis of the cultural presuppositions of builders in the past while considering the cultural presuppositions we have today [35]. This makes it possible to develop a discipline made up of multiple cross-cutting readings in the service of a complex object of study, based on the narrative capacity of history and with an awareness of the impossibility of factually recreating it. This study should, therefore, include the analysis of traces of building techniques (drawing, planning, calculations, simulation, execution, maintenance, and conservation) and functional programs (rooms, temples, fortifications, factories, bridges, infrastructures, and so on); materials (extraction, processing, and finishing); machinery and tools, the individual and collective training of all managers and craftspeople/labourers, and the dissemination of knowledge (courses and technical literature), the processes of work organization, professional associations, the public and private management of works; and the social, economic, political, and cultural contexts of building activity.

It is necessary to examine the logic of the action of each of the actors involved in all of these research areas, based not only on the systems in their contexts but also their individual paths in training and practice, changing the scale of analysis if necessary. The relational dimension of microhistory will also be vital in completing a reading of the macro moments of technological innovation. A study of the sources (economic literature, archives, buildings themselves, iconographical and audiovisual materials, and oral traditions) should focus not only on their contents and level of scholarship but also on the level to which they incorporate mentalities and mechanisms for the exchange of the knowledge they contain. Construction manuals are, in this case, good examples of theoretical and practical hybridization. In relation to methods, studies can and should be carried out at all levels: experimental (laboratory, modelling, simulation), historical (diachronic, synchronic), and in systemic cross-disciplinary synthesis.

\section{Seeking to Make an Ontology of the Culture of the Built Object}

The study of building cultures primarily involves examining certain processes of the materialization of a culture. In their own ways, philosophers such as Walter Benjamin (1892-1940) and Maurice Halbwachs (1877-1945) defended the idea that the city is the material manifestation of collective memory [36]. This idea of the reification of culture can be extended to the natural environment, landscapes, or territory. In reality, each time people build, nature is transformed according to the host culture.

The decision to create a building is the decision to destroy some part of the material universe. Things are destroyed, trees are felled, stone is broken, old homes are razed - to make things better. The attempt to improve by destruction is technological. Every technological act entails changes in two major relations: one between the human and the nonhuman world, another within the world of people. Technology requires sacrifice of extant materials that ultimately do not owe their presence to human beings, and so technology — the means of transforming the natural into the cultural —exists as an index of a culture's valuation of nature. Nature can be valued as an active or a passive resource. [32] (p. 11) 
In this respect, in order to create an ontology of our own culture, it is also necessary to create an ontology of our building cultures in the past and present, which are sometimes barely accessible in the traces of the historic past because we are also what and how we build.

\section{[... ] we can know ourselves with our own knowledge [ ... ] we are still the ones-who are capable of undertaking - this ontology of our culture [... ] by turning ourselves inside out like the fingers of a glove in order to examine our own culture ourselves. [37]}

Considering that the distinction between erudite and popular culture has been transcended, it would be appropriate to study a community's cultural capital or knowledge, based on the service of the building activities in a particular historical period and geographical area. As can be seen from the case of Portugal, construction history is not the story of architects and engineers or the story of everything linked to the activity of architects and engineers today. Neither is it the history of past restoration or conservation techniques, and much less so the history of construction science. Moreover, construction history must encompass not only the history of already well-known individual figures (engineers and architects) but also that of the founders and owners of construction companies, of master craftsmen, and of guild members. Such analyses should also be completed with the story of collective figures (construction companies, materials and machinery retailers, public and private institutions, associations, and so on), legislation, and technical literature for scientific and general consumption on each period of history.

\section{Discussion and Conclusions}

From the perspective of the Cartesian dialectic logic responsible for the establishment and institutionalization of many categories of knowledge as we understand them today, a logic which provides the starting point for this text, we must acknowledge the work that has already been done to expand on, explore in further depth, and enrich the subject and the debate around the history of construction. Nevertheless this work appears still—here and there-to be fragmented by research from different epistemological perspectives, in particular those defined by engineers and architects and by their roles in the construction industry. The situation of the history of architecture and the history of engineering in Portugal serves to illustrate the extent to which the study of how a community is built in a particular space and at a particular time is fragmented today.

This paper aims to show that when we accept that construction history entails the history of construction cultures, we accept a methodological approach that gives more complete sense to the fragmented and compartmentalised research undertaken in separate disciplines.

A set of clear historiographical injunctions confirmed by many studies presented at national and international conferences on construction history has been listed. Those injunctions justify a discussion on the nature and future of construction history as an autonomous discipline that integrates the history of culture and cultural histories, an autonomous discipline that is distinct from the history of architecture and the history of engineering.

The study of construction cultures entails the analysis of the transformation of a community's knowledge capital expressed in the activity of construction. In this way, construction history is presented as a broad field of knowledge integrating all the actors involved in that activity: collective actors (contractors, materials producers and providers, schools, associations, and institutions) and individual actors (engineers, architects, entrepreneurs, and craftsmen). For a given location and a given historical period, these actors build with specific technologies, tools, machines, and materials. Their activity is characterized by certain rules, laws, economies, knowledge transfer systems, and social organization. For all of these reasons, construction history should not seek to occupy the research space of the history of architecture or engineering since it already has a vast sphere of its own to study.

We are what and how we build. Construction history is a subject of study which takes into account the ways that the everyday is perceived and experienced in different cultures. For this reason, as is true of all categories of knowledge, construction history must constitute a construct under 
constant discussion if it is to provide a greater shared understanding of the problems involved in the millennia-old human activity, practised in the most diverse cultures of the world.

Funding: This research was funded by the FCT—Fundação para a Ciência e Tecnologia, Research Project "Portugal Builds 19_20: Digital Knowledge Platform for Portugal Construction History, 19th and 20th centuries" with the reference: PTDC/ARTDAQ/ 28984/2017.

Conflicts of Interest: The author declares no conflict of interest.

\section{References}

1. Becchi, A. L'histoire de la Construction/Construction History: Relevé d'un Chantier Européen/Survey of a European Building Site; Becchi, A., Carvais, R., Sakarovitch, J., Eds.; Classiques Garnier: Paris, France, 2018.

2. Huerta, F. Historia de la construcción: La fundación de una disciplina. In A História da Construção em Portugal. Alinhamentos e Fundações; Mascarenhas-Mateus, J., Ed.; Almedina, Centro de Estudos Sociais da Universidade de Coimbra: Coimbra, Portugal, 2011; pp. 31-48.

3. Addis, B. Some reflections on Construction History and how it may develop. In Proceedings of the Actas do $2^{\circ}$ Congresso Internacional de História da Construção Luso-Brasileira/2th International Congress on Luso-Brazilian Construction History Proceedings, Porto, Portugal, 14-16 September 2016; Póvoas, R.F., Mascarenhas-Mateus, J., Eds.; CEAU \& Faculdade de Arquitectura da Universidade do Porto: Porto, Portugal, 2016; pp. 61-74.

4. Oswalt, W.H. Habitat and Technology. The Evolution of Hunting; Holt, Rinehart and Winston: New York, NY, USA, 1973.

5. Petroski, P.H. The Evolution of Useful Things; Random House: New York, NY, USA, 1992.

6. Heitor, M.; Brito, J.; Rollo, M. Momentos de Inovação e Engenharia em Portugal no Século XXI; Dom Quixote: Lisboa, Portugal, 2004.

7. Laurier, P. Les Machines de Construction de L'antiquité à nos Jours: Une Histoire de L'innovation; Presses de l'ENPC: Paris, France, 1996.

8. Burguière, A. The Annales School: An Intellectual History; Cornell University Press: New York, NY, USA, 2009.

9. Rosenhead, J.; Mingers, J. Rational Analysis for a Problematic World Revisited: Problem Structuring Methods for Complexity, Uncertainty and Conflict; John Wiley \& Sons: Chichester, UK, 2001.

10. Chartier, R. Culture Écrite et Société. L'ordre des Livres (Xive-Xviiie Siècle); Albin Michel: Paris, France, 1996.

11. Benvenuto, E. La Scienza delle Costruzioni e il suo Sviluppo Storico-Critico; Sansoni: Firenze, Italy, 1981.

12. Sakarovitch, J. Epures D'architecture. De la Coupe des Pierres a la Géométrie Descrpitive, Xvi-Xixe Siècles; Birkhäuser: Basel, Switzerland; Boston, MA, USA; Berlin, Germany, 1998.

13. Kurrer, K.-E. The History of the Theory of Structures: From Arch Analysis to Computational Mechanics; Ernst \& Sohn: Berlin, Germany, 2008.

14. Harris, E. Principles of Archaeological Stratigraphy; Academic Press: San Diego, CA, USA, 1979.

15. Reveyron, N. L'apport de L'archéologie du Bâti Dans la Monographie D'architecture. Situ-Revue des Patrimoines. 2002. Available online: http://insitu.revues.org/1200 (accessed on 18 October 2019).

16. Tarr, J.; Dupuy, D. Technology and the Rise of the Networked City in Europe and America; Temple University Press: Philadelphia, PA, USA, 1988.

17. Tournikiotis, P. The Historiography of Modern Architecture; MIT Press: Cambridge, MA, USA; London, UK, 1999.

18. Frampton, K. Studies in Tectonic Culture, the Poetics of Construction in Nineteenth and Twentieth Century Architecture; MIT Press: Cambridge, MA, USA, 1995.

19. Martins, A.M.T.; Carlos, J.S. Built Heritage Research and History of Architecture: Light and Acoustic in the Cistercian Monastic Church of S. Bento de Cástris (Portugal). In IOP Conference Series: Materials Science and Engineering; IOP Publishing: Bristol, UK, 2019; Volume 603, p. 022054. Available online: https://iopscience.iop.org/article/10.1088/1757-899X/603/2/022054/pdf (accessed on 12 March 2020).

20. Vieira, B. Vis-a-vis da Fonte Luminosa. In Visões do Técnico, no Centenário 1911-2011; Branco, J., Dir., Ed.; ISCTE: Lisboa, Portugal, 2013; pp. 249-294. Available online: http://hdh.handle.net/10071/4497 (accessed on 20 September 2019).

21. Fernandes, J. Temas de Arquitectura e Urbanismo na África Portuguesa; Caleidoscópio: Casal de Cambra, Portugal, 2005. 
22. Milheiro, A.V. Nos Trópicos sem Le Corbusier. Arquitectura Luso-Africana no Estado Novo; Relógio d'Água: Lisboa, Portugal, 2012.

23. Mascarenhas-Mateus, J. Técnicas Tradicionais de Construção em Alvenarias. A Literatura Técnica de 1750 a 1900 e o seu Contributo Para a Conservação de Edifícios Históricos; Livros Horizonte: Lisboa, Portugal, 2002.

24. Mascarenhas, J. Sistemas de Construção. O edifício de Rendimento da Baixa Pombalina de Lisboa; Livros Horizonte: Lisboa, Portugal, 2004.

25. Maranha das Neves, A. História Recente da Engenharia em Portugal. Os engenheiros portugueses. A construção de uma identidade. In Proceedings of the Conference at the Instituto Superior Técnico, Lisboa, Portugal, 21 September 2010; Available online: https://fenix.tecnico.ulisboa.pt (accessed on 20 October 2019).

26. Brito, J.; Heitor, M.; Rollo, F. Engenho e Obra-Uma Abordagem à História da Engenharia em Portugal no Século XX; Dom Quixote: Lisboa, Portugal, 2002.

27. Guerra, F. História da Engenharia em Portugal; S.N.: Porto, Portugal, 1995.

28. Leach, N. Rethinking Architecture: A Reader in Cultural Theory; Routledge: London, UK; New York, NY, USA, 1997.

29. Borden, I.; Rendell, J. InterSections: Architetural Histories and Critical Theories; Routledge: London, UK; New York, NY, USA, 2000.

30. Huerta, S. Proceedings of the First International Congress on Construction History. Madrid, 20-24 January; Instituto Juan de Herrera, Sociedad Española de Historia de la Construcción: Madid, Spain, 2003; Available online: http://www.sedhc.es/congresos/index.php?id_cng=4 (accessed on 15 March 2020).

31. Proceedings of the First and Second International Conferences and Proceedings of the Spanish National Conferences. Available online: http://www.sedhc.es/congresos (accessed on 15 February 2020).

32. Glassie, H. Architects, vernacular traditions and Society. Tradit. Dwell. Settl. Rev. 1990, 1, 9-21.

33. Morley, J. Building Themes in Construction History. In Construction History; Oxfordshire: Abingdon, UK, 1987; Volume 3, pp. 13-30.

34. Davis, H. The Culture of Building; Oxford University Press: New York, NY, USA, 2006.

35. White, H. The Practical Past; Northwestern University Press: Evanston, UK, 2014.

36. Berdet, M. Benjamin Sociographe de la Mémoire Collective? Temporalités 2005. Available online: http: //temporalites.revues.org/410 (accessed on 30 October 2019).

37. Foucault, M. Michel Foucault à Propos du Livre "Les Mots et les Choses". Interview de Michel Foucault par Pierre Dumayet, INA, 15 June 1966. Available online: http://www.ina.fr/video/I05059752 (accessed on 27 November 2019). 